\title{
The Power of Words in Denisa Chavez's Face of an Angel
}

\section{Amaia Ibarrarán Bigalondo University of the Basque Country}

fipibbia@vc.ehu.es

\begin{abstract}
The last two decades have witnessed the emergence of the Chicana voice, a voice that has struggled to rewrite her story in order to reinterpret the atrophied archetypes manifest in the male stories and Literature. Retelling her true story, the Chicana heals the wound that has kept her voiceless and paralyzed. Storytelling, thus, becomes powerful medicine for her, and an appropriate means of shaping an identity that has been silent and transparent throughout the ages. Denise Chávez's Face of an Angel, published in 1994, chronicles the story of Soveida Dosamantes, a woman who chooses the tell her life-story in order to assert herself in her roots and identity, which has been strongly influenced by the constant, powerful presence of women around her. The novel pays homage to the women in the author's and the main protagonist's families, who, even though denied the right to speak publicly, have perfectly fulfilled the role of cultural bearers for the community and have, at the same time, understood and transmitted the need to raise their voice and fight for an active feminine role within their group, in a bid to demystify the colonized image of the Chicana.
\end{abstract}

Stories are medicine. I have been taken with stories since I heard my first. They have such power; they do not require that we do, be, act anything-we need only listen. The remedies for repair or reclamation of any lost psychic drive are contained in stories ... Stories are embedded with instructions which guide us about the complexities of life. Stories enable us to understand the need for and the ways to raise a submerged archetype" (Pinkola, 1992: 15-16). 
The history of the Chicana: a collection of untold stories, a long period of silence, an unspoken voice, lives forever unaccounted. The femenine has always been related to storytelling, and Chicana women, like many other women worldwide, have been the narrators of a story that has kept them in the background, fulfilling the role of cultural bearers, but never having been recognized as such. Paradoxically, whilst women have indeed spoken and transmitted ideas about their community, it has been the community (personified in the ruling men) that has always had the power to speak about these women. Stereotypes of women have been created, dispersed and presented as the only true images of Chicanas.

The last two decades have witnessed the emergence of the Chicana voice, a voice that has struggled to rewrite her story in order to reinterpret the atrophied archetypes manifest in the male stories and literature. Retelling her true story, the Chicana heals the wound that has kept her voiceless and paralyzed. Storytelling, thus, becomes powerful medicine for her, and an appropiate means of shaping an identity that has been silent and transparent throughout the ages. Naming and giving a real shape to the sources of her oppression, the Chicana is able to create her own image, the true reflection of her identity. The stories of the relationships between women, mothers and daughters, friends and relatives, start to be re-membered, thus, overcoming the fear to take real women's lives to the forefront of public life. The feminine line (grandmother, mother, daughter) which is the basis of the transmission of culture and tradition within the family (and therefore, the community), now becomes the vehicle through which the new ideas, embedded in the old stories, circulate and assume importance within the quest for the Chicana's free, decolonized identity.

For this reason, the split subject is always searching for a retrospective unity. That may explain, in part, why the need to connect with one's ancestral collective consciousness, and with history, has become such a necessity for Chicana writers ... There is also a need to tell as if you belong, especially when you are told time after time that you do not (Rebolledo, 1995: 146).

As a result, words, both in the form of oral and written discourse, become powerful, for they are the bearers of the revolutionary ideas that women's voices convey, and create a sense of unity and belonging, a privilege that had always been denied to Chicanas. They had always been regarded as passive objects in the shaping of the community and had therefore never experienced the idea of being part of it. Despite this, the community has always owned their lives, bodies and voices.

Denise Chavez's Face of an Angel, published in 1994, chronicles the story of Soveida Dosamantes, a woman who chooses to tell her life-story in order to assert herself in her roots and identity, which has always been strongly influenced by the constant, powerful presence of women around her. The novel pays homage to the women in the author's and the main protagonist's families, who, even though denied the right to speak publicly, have perfectly fulfilled the role of cultural bearers for the community and have, at the same time, helped their grand-daughters and daughters so understand the need to raise their voice and fight for an active feminine role within the Chicano community in a bid to demystify the 
colonized image of the woman, transmitted through time. Opening her novel with the following words, "My grandmother's voice was rarely heard, it was a whisper, a moan. Who heard?../.My mother's voice cried out in rage and pain. Who heard? .../... My voice is strong. It is breath. New Life. Song. Who hears?...", the author states from the very beginning that she is ready to speak aloud to reinterpret and recreate the myths Chicana women have always been associated with.

Soveida is a strong woman who represents the contemporary woman who is fully aware of the source of her oppression and is only too eager to dismantle it. Myths of women's guilt such as the Malinche, that have justified the fact that women did not have the right to speak, as a punishment for having betrayed their community, are challenged in the novel. She says:

In the past, our men had power, and their women couln't speak. When they did, it was with the Malinche voice, called the voice of the betrayer. That's were all began. What do we know of Malinche, anyway? That she was the translator for Cortés, that she became his mistress, the mother of his children, and, in turn, the betrayer of a race, a culture. That is what men say. Malinche is Eve again, or any number of other so-called evil ones. Why must the snake have convinced the woman of eternal life? It is because men would have us believe that the Father God created Adam and that He took Eve from that man's ribs? The first woman, we are told, came from a man. And why didn't he, instead, come out of her vagina, a small speck of holy, living juice, originating in the sex of the Mother God?

Who wrote the words that would betray all women? Men. And who allowed that betrayal? Women. Who perpetuated that betrayal? Mothers. ... Isn't it time for women to break those chains of oppression? Isn't it time for that endless cycle of self-hatred to cease? (Chávez, 1989: 317).

As portrayed throughout the novel and in the Chicanas' quest for their real identity, words, or the lack of words in the case of the Chicanas, are portrayed as the basis of women's oppression. Forever denied the right to speak, the Chicana has assimilated and obeyed the ways of her master, perpetuating the image of the silent Chicana who does not dare to speak, and who teaches this to her sons and daughters. Men, following the Christian myth of creation, which presents women as sinful, inferior creatures, have never allowed women to practice and experiment with words, thus, denying them the power of creation. They have no right to create their own identity, or to see themselves as the creators of life. Just like the animals, women were not given the gift of speech and had to rely on men to speak on their behalf. Soveida blames women who, having assimilated their situation of "natural silence" and, at the same time, believed all the negative myths related to their identity, use their power to transmit the cultural heritage and traditions in a self-destructive way, educating their children in the belief that women are inferior to men and have no ability to speak.

Always women have felt that their voices didn't count, or at least, in the way a man's voice counted. We have been sterile despite the fecundity of our wombs. The children we 
bring to this world are monsters who would oppress and destroy and defile the generations of children they will never see (Chávez, 1989: 318).

Sofia's aim, as portrayed throughout the novel, is to free women from the burden of silence, a silence which has taken them to situations as dramatic as the one mentioned above. Chávez also endeavours to reinterpret the old myths and stereotypes, providing them with a new, revolutionary reading, which would help women feel a sense of belonging within a community that recognizes their importance. The figure of the woman-as-server is reviewed in the novel, as well as in Sofia's life. She works as a waitress, a job historically done by women, which signifies a symbol of serving. The woman-waitress is the womanmother-wife-companion, who has to obey and fulfil her task in a submissive, though, positive way. Soveida starts to write The Book of Service, an essay believed to transmit the secrets of waitressing to other waitresses, as well as to dignify a job that has never been socially seen as "important" (just like women's tasks). The fact of naming and talking about the art of serving becomes the process of positivization of the stereotype of the woman who serves, and at the same time plays an important role within the community. Soveida's writing becomes revolutionary and political, and in a more personal way, positive and liberating.

I wish you the best, always. I wish someone had handed me The Book of Service when I was a young waitress. It would have saved me time, worry and pain. Never forget who you are, and where you come from. Never forget that the work you do is important and full of lessons (Chávez, 1989: 451).

Telling stories, therefore, is a source of liberation and the materialisation of a sense of unity of the different subjects within a community. Sharing thoughts and words is healing and transmitting these words, necessary. Once again, the image of the woman as a cultural bearer is elevated in the novel and becomes important as the source of the natural flow of traditions and of their interpretation. However, when telling is presented as something imposed or colonized, it may become counterproductive and painful. Soveida is asked to write for her class by J.V. Velásquez, her teacher, who is the personification of the man who mistrusts the fact that women have acquired a powerful voice.

Dear Ms. Dosamantes:

You have an impassioned flair for words. You argue with great emotion and sensitivity, and yes, you have a feel for your topic. The idea is interesting, but it does not fully succeed. The ideas that you postulate for the continuing cycle of machismo seem old and hackneyed. Step into the present! Not all men are as you present them in this feminist diatribe. Heated feelings alone do not make your case. Your thesis is never clearly identified, you jump from idea to idea, and the whole lacks cohesion. Check your grammar, syntax, and use of the possessive. They are all awful. On top of this, you have no footnotes. This is a college class. Have you written other term papers? I suggest you 
study the Harbrace Handbook. I would be happy to help you formulate an outline for your next paper. Your writing is impressive, but your scholarship leaves much to be desired. Content: C

Presentation: C-

J.V. Velásquez, Ph D. (Chávez, 1989: 321).

As portrayed in the persona of J.V. Velásquez, men attempt to control women's voices, deciding when and what they should speak about, only to subsequently criticize them for having done so. The depiction of Soveida's essay as lacking cohesion, being grammatically incorrect, and of having a content that does not deserve any kind of recognition, reveals the idea perpetuated throughout the centuries of the voiceless, languageless, and therefore, powerless woman. The paternalistic tone his criticism adopts implies superiority and a dominance-based relationship, which leaves the woman defenceless, and once again, unable to use words to express her rights, worries and deeper concerns. On the other hand, the language Soveida and the rest of the women use is a language created and thought to maintain and perpetuate male dominance over women, and is not valid for the expression of the real identity of each Chicana.

Following the task adopted by Chicana feminists of the reinterpretation and rereading of the myths that sustain the Chicano community, Soveida faces the situation and chooses to continue writing in order to go beyond the language barrier that her teacher has imposed on her. Writing therefore becomes a journey within, which helps her reformulate the story of her community. The Chicana critic Rosaura Sánchez (1997: 350) explains that

These "identity essays", though inspired by identification with some collectivity, often tend to become fundamentally self-reflexive and individualist in focus, as the writer assumes an ethnographic-- gender, race and ethnicity, nationality, sexual orientation, religion, or autobiographical mode, where the "I" that identifies on the basis of career is analyzed as a textual site for defining and interpreting a group's particularism.

In the figure of Soveida Denise Chávez personifies the woman who struggles so that her voice is heard and accounted for. Storytelling, symbolized in the fact of writing in this particular novel, is important for the search and subsequent transmission of the new, womanly created feminine myths, which convey a more respectful and integrating vision of women's reality. Denouncing the fact that men have also attempted to colonize this emerging voice, the author calls for a voice free of the chains of the social conventions and rules, that, once again, try to impose silence, or a controlled speech, upon women.

As Chicana writers embark on the process of writing, finding and giving voice- a process often viewed as otherworldly, mysterious. the first question that comes to mind is "Why? Why write at all?... As discussed previously, part of the answer lies in the fact that writing, for many Chicanas, is a political struggle. It is a struggle not to let oneself be dominated and colonialized (Rebolledo, 1995: 158). 
In the case of Face of an Angel, telling the story of a woman who choses to write and demystify the image of the woman as a "non-important-server-of-the-community", words become a powerful means to criticize the male community's efforts to perpetuate the negative female stereotypes and the colonization of her voice. On the other hand, in the case of Soveida, writing becomes the means of validating and recognizing the importance of her role and her words within the community, as well as perpetuating the task of women as bearers of a rich and tolerant cultural heritage that account for women's stories.

We had to write another story: a mujer story, another discourse from the perspective of the foregrounded Chicana.

We Chicanas had to create our own word, our own cosmos, constructed by "Chicana"here, sister, woman (Chabram, 1991: 86).

\section{Works Cited}

Arango-Keeth, Fanny (1993): "La abuela puso al revés el mundo de Joaquín: Representación Matrilineal y la nueva mujer chicana." Mester XXII(2).

Chabram-Dernersesian, Angie (1991): "I Throw Punches for my Race, but I don " $t$ want to be Man: Writing Us-Chicanos (Girl, Us)/Chicanas-into the Movement Script", Cultural Studies. Routledge. Cit. in Arango-Keeth (1993).

Chávez, Denise (1989): Face of an Angel. Houston, TX: Arte Público Press.

Pinkola Estés, Clarissa (1992): Women Who Run with the Wolves. Myths and Stories of the Wild Woman Archetype. New York: Ballantine.

Rebolledo, Tey Diana (1995): Women Singing in the Snow. A Cultural Analysis of Chicana Literature. " Tucson: University of Arizona Press.

Sánchez, Rosaura (1997): "Reconstructing Chicana Gender Identity." American Literary History XIX: $350-362$. 